\title{
Electrochemical degradation of aqueous alachlor and atrazine: products identification, lipophilicity, and ecotoxicity
}

\author{
Rafaely Ximenes de Sousa Furtado+(i), Eduardo Bessa Azevedo ${ }^{\circledR}$, Artur de Jesus Motheo
}

University of São Paulo (USP), São Carlos Institute of Chemistry, 400 Trabalhador São Carlense Ave, São Carlos, São Paulo, Brazil

+Corresponding author: Rafaely Ximenes de Sousa Furtado, phone: +55 163373 9932, email address: rafaelyximenes@hotmail.com

\section{ARTICLE INFO}

Article history:

Received: January 7, 2019

Accepted: March 7, 2019

Published: November 20, 2019
Keywords:

1. alachlor

2. atrazine

3. electrochemical degradation

4. DSA

5. ecotoxicity

ABSTRACT: This work studied the electrochemical degradation of alachlor and atrazine (alone and mixed with each other) using a filter-press cell, a dimensionally stable anode (DSA Ti/ $\mathrm{Ru}_{0.3} \mathrm{Ti}_{0.7} \mathrm{O}_{2}$ ), initial $\mathrm{pH} 3.0$, and temperature at $25{ }^{\circ} \mathrm{C}$. The best operational conditions for alachlor $\left(0.33 \mathrm{mmol} \mathrm{L}^{-1}\right)$ degradation were obtained by a $3^{2}$ factorial design, in which the factors/levels were: $\mathrm{NaCl}$ concentration $(0.05,0.1$, and $\left.0.15 \mathrm{~mol} \mathrm{~L}^{-1}\right)$ and current density $\left(10,30\right.$, and $\left.50 \mathrm{~mA} \mathrm{~cm}^{-2}\right)$. Thus, $93.1 \%$ alachlor removal and $71.2 \%$ mineralization were achieved using $0.15 \mathrm{~mol} \mathrm{~L}^{-1} \mathrm{NaCl}$ and $30 \mathrm{~mA} \mathrm{~cm} \mathrm{c}^{-2}$. In addition, the initial degradation products (DPs) of alachlor and atrazine were identified by liquid chromatography coupled to mass spectrometry (LC-MS). Acute and chronic ecotoxicities for three trophic levels (fishes, daphnids and green algae) and lipophilicity ( $\log \mathrm{D}, \mathrm{pH} 7.4)$ of the DPs were also estimated using the ECOSAR 1.11 and ChemAxon Calculator software, respectively. The present study showed that the electrochemical degradation is an efficient method for removing the herbicides alachlor and atrazine from water and that the DPs formed have lower pollution potential than their original compounds.

\section{Introduction}

Alachlor (2-chloro-N-(2,6-diethylphenyl)-N(methoxymethyl)acetamide) is one of the most frequently used herbicides in weed control, early inhibiting their development. This compound belongs to the chloroacetamide class and it is widely used to protect corn, rice, soybean, peanut, and cotton crops ${ }^{1}$. Alachlor can be degraded by microorganisms present in soils. Therefore, both alachlor and its main metabolite, 2,6diethylaniline, are ubiquitous in the environment and cause serious ecological and physiological problems $^{2,3}$. Alachlor is a toxic, carcinogenic, persistent organic compound (with a half-life of 70 days in soil and 30 days in water), and an endocrine

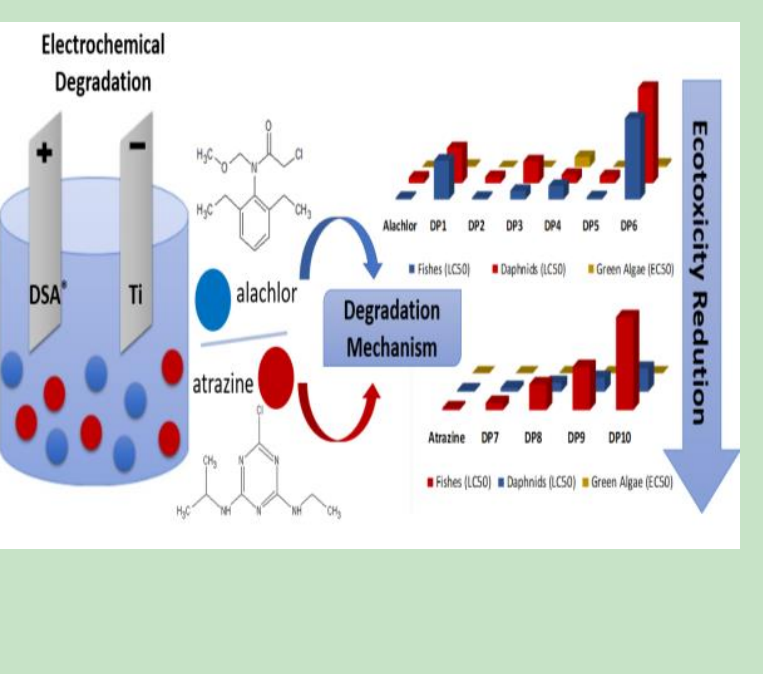

disruptor $^{4-7}$. The contamination of water resources by alachlor occurs due to runoff and infiltration, causing it to be frequently detected in surface and groundwater samples ${ }^{8-10}$.

Atrazine

(1-chloro-3-ethylamino-5isopropylamino-2,4,6-triazine), as well as alachlor, is widely used in weed control in maize, sugarcane, and soybean crops. This herbicide belongs to the triazines group, and it is the most important chemical of this family as well as one of the most used herbicides in the world due to its high phytotoxic activity ${ }^{11,12}$. Among its main characteristics are: low vapor pressure, moderate solubility in water, slow hydrolysis, and the ability of leaching ${ }^{13,14}$. Besides that, atrazine is also a carcinogenic compound and an endocrine 
disruptor. For human consumption, atrazine concentration in water shall not exceed $3 \mu \mathrm{g} \mathrm{\textrm {L } ^ { - 1 }}$. However, higher concentrations are frequently detected in surface and groundwater ${ }^{15,16}$.

Alachlor and atrazine are the main active ingredients in many commercial herbicide formulations, which may, in some cases, consist of a mixture of atrazine and alachlor ${ }^{17}$. These formulations have their selective action due to the mixture of the two herbicides that complement each other. The intensive use of these compounds associated with their persistence in the environment and their low biodegradability has contributed to their frequent detection in water. Therefore, it is necessary to develop new methodologies capable of removing those compounds from aqueous systems, since conventional water and sewage treatment plants are inefficient in doing so ${ }^{18-21}$.

Among the available methodologies for the treatment of wastewaters containing organic compounds such as alachlor and atrazine, the electrochemical method is very promising. It has been gaining prominence in scientific community due to its versatility, easy automation, high organic removal rate, immobilization of the catalyst in the electrode, and the formation of reactive species on the surface of the electrode ${ }^{13,22-26}$.

In electrochemical oxidations, the choice of the material with which the anode is made is of fundamental importance, because the efficiency and selectivity of the process depends on it. Among the most frequently used anodes for the removal of organic compounds is the dimensionally stable anode (DSA) with a nominal composition $\mathrm{Ti} / \mathrm{Ru}_{0.3} \mathrm{Ti}_{0.7} \mathrm{O}_{2}{ }^{27}$. It has been used in the chloralkali industry for several years due to its mechanical stability and catalytic activity ${ }^{28,29}$. Several studies report the successful use of the DSA anode ${ }^{28,30-34}$.

The feasibility of a treatment technology should not be assessed only by its potential for degrading a pollutant, but also by the generation of less ecotoxic and more hydrophilic compounds (less prone to bioaccumulation and biomagnification).

Partition coefficients $(\log \mathrm{P})$ and distribution coefficients $(\log \mathrm{D})$ are the ratios of the concentrations of a compound in a mixture of two immiscible solvents at equilibrium. Log $\mathrm{P}$ generally refers to the non-ionized compound, whereas $\log \mathrm{D}$ refers to the concentration ratio of all species of the compound (ionized and nonionized). Therefore, the latter coefficient is $\mathrm{pH}$ - sensitive. Typically, the most useful $\mathrm{pH}$ is 7.4 , the physiological one $\mathrm{s}^{35,36}$. When one of the solvents is water and the other is a nonpolar solvent (usually n-octanol), then those coefficients are a measure of lipophilicity (or hydrophobicity).

Finally, the objective of this work was to study the electrochemical degradation of the herbicides alachlor and atrazine, in a flow cell, using a DSA anode $\left(\mathrm{Ti} / \mathrm{Ru}_{0.3} \mathrm{Ti}_{0.7} \mathrm{O}_{2}\right)$, assessing the influence of different concentrations of electrolyte and current densities on the removal and mineralization of the organic compounds, besides proposing their respective routes of degradation. The ecotoxicity and lipophilicity of the identified degradation products (DPs) were also estimated.

\section{Materials and methods}

\subsection{Cyclic voltammetry}

Cyclic voltammetry (CV) was used to obtain qualitative information about the reaction on the electrode/solution interface. Cyclic voltammograms were obtained using a potentiostat/galvanostat (Autolab, PGSTAT128) and a conventional electrochemical cell composed of: (a) working electrode: circular, dimensionally stable anode plate (DSA) manufactured by De Nora do Brasil Ltda. (nominal composition: $\mathrm{Ti} / \mathrm{Ru}_{0.3} \mathrm{Ti}_{0.7} \mathrm{O}_{2}$; exposed geometric area: $1 \mathrm{~cm}^{2}$ ); (b) counter electrode: titanium plate $\left(2 \mathrm{~cm}^{2}\right)$ parallel to the working electrode; and (c) reference electrode: normal hydrogen electrode (NHE). The assays were performed using $50 \mathrm{~mL}$ of $0.05,0.1$, and $0.15 \mathrm{~mol} \mathrm{~L}^{-1} \mathrm{NaCl}$ as the supporting electrolyte. Cyclic voltammograms of atrazine and alachlor (both at $0.33 \mathrm{mmol} \mathrm{L}^{-1}$ ) in $\mathrm{NaCl} 0.15 \mathrm{~mol} \mathrm{~L}^{-1}$ were also obtained. The potential window was $0.4-1.6 \mathrm{~V}$ versus NHE, with scanning speed of $50 \mathrm{mV} \mathrm{s}^{-1}$.

\subsection{Electrochemical degradation experiments}

The degradation experiments were performed in a filter-press flow-cell using: (a) a commercial DSA $\mathrm{Ti} / \mathrm{Ru}_{0.3} \mathrm{Ti}_{0.7} \mathrm{O}_{2}$ with surface area equal to $14 \mathrm{~cm}^{2}$ (working electrode); (b) a titanium plate with area equal to $14 \mathrm{~cm}^{2}$ (counter electrode); (c) a normal hydrogen electrode (NHE) (reference electrode), and (d) a commercial cationic membrane strip (Ionac, MC-3470), immersed in $0.5 \mathrm{~mol} \mathrm{~L}^{-1} \mathrm{H}_{2} \mathrm{SO}_{4}$, providing the electric contact between the electrochemical cell and the reference electrode (Fig. 1). Besides that, a centrifugal pump 
drove the electrolytic solution through the flowcell. This solution was magnetically stirred.

Initial $\mathrm{pH} 3$, temperature $25{ }^{\circ} \mathrm{C}$, flow rate $130 \mathrm{~mL} \mathrm{~min}^{-1}$ and solution volume $200 \mathrm{~mL}$ were held constant throughout the experiments.

Initially, only alachlor $\left(0.33 \mathrm{mmol} \mathrm{L}^{-1}\right)$ was degraded. The experiments followed a $3^{2}$ full factorial design with the central point in triplicate (Statistica 7 software). The studied factors and levels were supporting electrolyte sodium chloride concentration $\left(0.05,0.1\right.$, and $\left.0.15 \mathrm{~mol} \mathrm{~L}^{-1}\right)$ and current density $\left(10,30\right.$, and $50 \mathrm{~mA} \mathrm{~cm} \mathrm{~cm}^{-2}$.

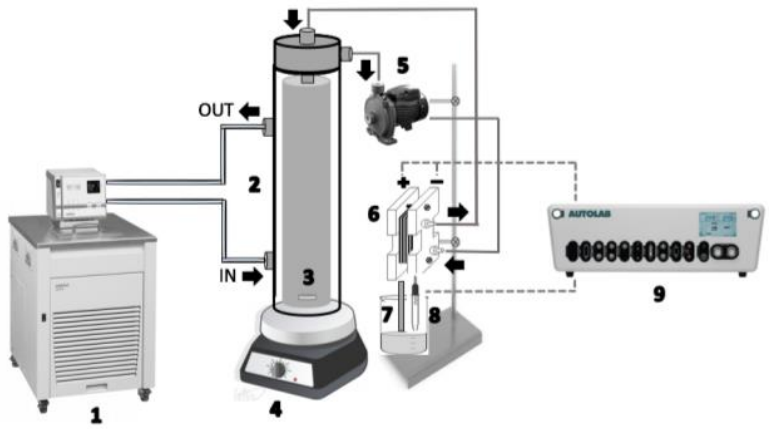

Figure 1. scheme of the experimental apparatus: 1) Thermostat bath; 2) reservoir; 3) magnetic bar; 4) magnetic stirrer; 5) centrifugal pump; 6) flow cell; 7) cationic membrane; 8) reference electrode; and 9) potentiostat/galvanostat.

\subsection{Analytical procedures}

Total organic carbon analyses (TOC, Shimadzu TOC-VCPH Total Organic Carbon Analyzer) were performed to determine the amount of organic matter in solution, before and after the treatment.

The concentrations of alachlor and atrazine were measured in a high-performance liquid chromatograph (HPLC, Shimadzu LC-10AD VP) equipped with a UV detector (Shimadzu LC10AVP) and a $\mathrm{C}_{18}$ reversed-phase column (Zorbax SB-C $\left.\mathrm{C}_{18}, 5 \mu \mathrm{m}, 25 \mathrm{~cm} \times 4.6 \mathrm{~mm}\right) .20 \mu \mathrm{L}$ were isocratically eluted using a mobile phase composed of acetonitrile and water 70:30 (in volume), flow rate $1 \mathrm{~mL} \mathrm{~min}^{-1}$, temperature $40{ }^{\circ} \mathrm{C}$ and $\mathrm{UV}$ detection at $210 \mathrm{~nm}$.

The degradation products (DPs) were identified in a high-performance liquid chromatograph (HPLC, Thermo Scientific Accela 1250 Pump) coupled with a LTQ-Orbitrap Velos spectrometer (HPLC-MS, Thermo Fisher Scientific), operating under the following conditions: positive ion mode electrospray ionization (ESI), electrospray voltage $3.7 \mathrm{kV}$, nebulization gas pressure $75 \mathrm{psi}$, heater temperature $500{ }^{\circ} \mathrm{C}$, capillary temperature $400{ }^{\circ} \mathrm{C}$, and injection volume $10 \mu \mathrm{L}$. $\mathrm{A} \mathrm{C}_{18}$ reversed phase column (Zorbax SB-C $18,5 \mu \mathrm{m}, 25 \mathrm{~cm} \times 4.6 \mathrm{~mm}$ ) and a mobile phase composed of acetonitrile and formic acid $0.1 \%$ (70:30 in volume), isocratic mode, and flow rate $1 \mathrm{~mL} \mathrm{~min}{ }^{-1}$ were used.

\subsection{Calculations}

Ecotoxicities were estimated for three trophic levels (fishes, daphnids and green algae) using the ECOSAR 1.11 software (USEPA, 2017). The acute indicators: $\mathrm{LC}_{50}$ (lethal concentration to $50 \%$ of the tested organisms) and $\mathrm{EC}_{50}$ (effect concentration to $50 \%$ of the tested organisms) were estimated. Chronic ecotoxicities were estimated as the geometric mean of the LOEC (lowest-observedeffect concentration) and the NOEC (no-observedeffect concentration). Lipophilicity ( $\log \mathrm{D})$ values were calculated with the aid of the ChemAxon Calculator.

\section{Results and discussion}

\subsection{Cyclic voltammetry of atrazine and alachlor}

Figure 2a shows the cyclic voltammograms of the commercial DSA electrode using $\mathrm{NaCl}$ as the supporting electrolyte in the following concentrations: 1) 0.05 , 2) 0.1 and 3) $0.15 \mathrm{~mol} \mathrm{~L}^{-1}$. Figure $2 \mathrm{~b}$ shows the voltammetric behavior of the commercial DSA electrode with solutions $0.15 \mathrm{~mol} \mathrm{~L}^{-1} \mathrm{NaCl}$ in the presence of 4) alachlor $\left(0.33 \mathrm{mmol} \mathrm{L}^{-1}\right)$ and 5) atrazine $\left(0.33 \mathrm{mmol} \mathrm{L}^{-1}\right)$. One can observe that from 0.4 to $1.2 \mathrm{~V}$ vs. NHE, no significant increase of the density current occurs; however, for potentials above $1.2 \mathrm{~V}$, there was a fast increase in density current, characterized by the oxygen evolution reaction (OER) and chlorine evolution (Eqs. 1 and 2) ${ }^{27,29}$.

$2 \mathrm{H}_{2} \mathrm{O} \rightarrow \mathrm{O}_{2}+4 \mathrm{H}^{+}+4 \mathrm{e}^{-}$
$2 \mathrm{Cl}^{-} \rightarrow \mathrm{Cl}_{2}+2 \mathrm{e}^{-}$ 

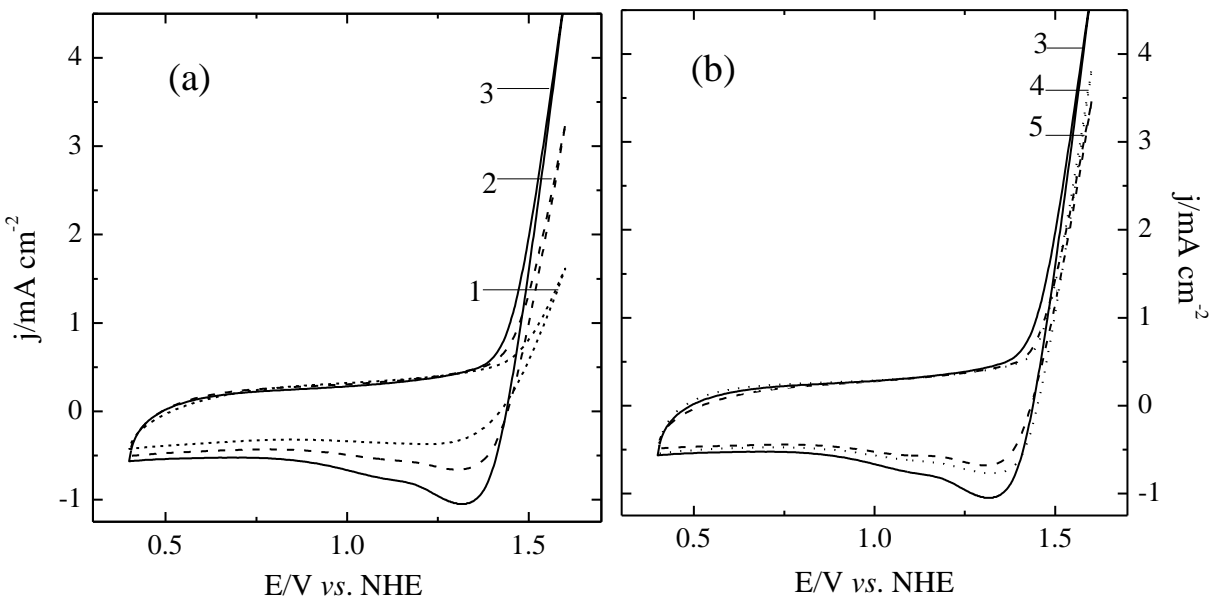

Figure 2. Cyclic voltammograms of the commercial DSA electrode $\left(\mathrm{Ti} / \mathrm{Ru}_{0.3} \mathrm{Ti}_{0.7} \mathrm{O}_{2}\right)$ recorded between 0.4 and $1.6 \mathrm{~V}$ vs. NHE at $50 \mathrm{mV} \mathrm{s}^{-1}$ in aqueous solutions containing: (a) $0.05,0.1$, and $0.15 \mathrm{~mol} \mathrm{~L}^{-1} \mathrm{NaCl}$ (lines 1,2 , and 3, respectively) and (b) alachlor $0.33 \mathrm{mmol} \mathrm{L}^{-1}$ (line 4 ) and atrazine $0.33 \mathrm{mmol} \mathrm{L}^{-1}$ (line 5).

In Figure 2a, it can be observed that oxygen and chlorine evolution reactions became more evident with increasing concentrations of $\mathrm{NaCl}$. However, when the herbicides were added to the $0.15 \mathrm{~mol} \mathrm{~L}^{-1}$ $\mathrm{NaCl}$ solution (Fig. 2b), a gradual decrease in current density was noticed for potentials over $1.2 \mathrm{~V}$. That may happen because the adsorption of the herbicides and/or electrogenerated DPs on the anode surface, blocks the electrode active sites ${ }^{19,30}$.

\subsection{Electrodegradation study}

\subsubsection{Study of the alachlor electrochemical degradation by factorial design}

Table 1 shows the obtained results for alachlor degradation after $120 \mathrm{~min}$ of electrolysis (as alachlor was harder to degrade than atrazine, the best operational conditions for the former were also used with the latter).

Table 1. Alachlor removal and mineralization obtained after the electrochemical treatment $\left(3^{2}\right.$ full factorial design with the central point in triplicate).

\begin{tabular}{|ccccc|}
\hline Experiment & $\mathbf{j} / \mathbf{m A ~} \mathbf{~}^{-\mathbf{2}}$ & $\mathbf{C}_{\mathbf{N a C}} / \mathbf{m o l ~ L}^{-\mathbf{1}}$ & Alachlor removal/\% & TOC/\% \\
\hline $\mathbf{1}$ & 10 & 0.05 & 85.0 & 19.4 \\
\hline $\mathbf{2}$ & 10 & 0.10 & 88.0 & 20.4 \\
\hline $\mathbf{3}$ & 10 & 0.15 & 89.5 & 21.7 \\
\hline $\mathbf{4}$ & 30 & 0.05 & 86.5 & 45.2 \\
\hline $\mathbf{5}$ & 30 & 0.10 & 87.4 & 70.1 \\
\hline $\mathbf{6}$ & 30 & 0.15 & 93.1 & 71.2 \\
\hline $\mathbf{7}$ & 50 & 0.05 & 88.0 & 67.5 \\
\hline $\mathbf{8}$ & 50 & 0.10 & 91.7 & 70.4 \\
\hline $\mathbf{9}$ & 50 & 0.15 & 93.5 & 71.6 \\
\hline $\mathbf{1 0}$ & 30 & 0.10 & 88.0 & 67.7 \\
\hline $\mathbf{1 1}$ & 30 & 0.10 & 87.0 & 68.7 \\
\hline & Experimental Error/\% & & 0.5 & 1.2 \\
\hline
\end{tabular}


It was possible to assess the effect of the investigated factors on the response-variables (removal evaluated by HPLC and the respective mineralization expressed by TOC values) to determine which of them were statistically significant with a 95\% confidence interval (within tested levels). Both factors were significant, and the best tested treatment condition was $0.15 \mathrm{~mol} \mathrm{~L}^{-}$ ${ }^{1} \mathrm{NaCl}$ and current density equal to $50 \mathrm{~mA} \mathrm{~cm}{ }^{-2}$, since the higher the current density and the electrolyte concentration, the higher the removal $(93.5 \%)$ and the mineralization $(71.6 \%)$. However, $0.15 \mathrm{~mol} \mathrm{~L}^{-1} \mathrm{NaCl}$ and current density equal to $30 \mathrm{~mA} \mathrm{~cm}^{-2}$ were chosen as the actual treatment conditions due to lower electric energy requirements and to the fact that the removal (93.1\%) and the mineralization (71.2\%) obtained were quite close to the ones at the best tested conditions.

\subsubsection{Effect of electrolyte concentration and current density}

The $\mathrm{NaCl}$ concentration affects the production of radicals (and therefore, the oxidation capacity) and current density. These are important parameters for the electrodegradation of any organic compound ${ }^{30,37}$.

The obtained results (Table 1) show that increasing current density with a fixed $\mathrm{NaCl}$ concentration led to higher removal and mineralization. This same behavior was observed for a fixed current density while increasing the electrolyte concentration. Under all studied conditions, alachlor removals were greater than $80 \%$. However, in none of them the complete removal or mineralization were achieved.

Degradation may take place by two mechanisms: i) the organic compound is adsorbed on the anode surface and then oxidized by anodic electron transfer reaction - direct oxidation; and ii) it reacts with generated active chlorine species with high oxidizing power, according to Eqs. 2, 3 and 4 - indirect oxidation ${ }^{38,39}$.

$\mathrm{Cl}_{2}+2 \mathrm{H}_{2} \mathrm{O} \leftrightarrows \mathrm{HClO}+\mathrm{H}_{3} \mathrm{O}^{+}+\mathrm{Cl}^{-}$
$\mathrm{HClO}+\mathrm{H}_{2} \mathrm{O} \leftrightarrows \mathrm{H}_{3} \mathrm{O}^{+}+\mathrm{ClO}^{-}$

Hypochlorous acid $\left(\mathrm{E}^{\mathrm{o}}=1.49 \mathrm{~V}\right.$ vs. $\left.\mathrm{NHE}\right)$ act as the main oxidizing agent in the degradation reactions due to its greater oxidation power in comparison to the other electrochemically generated active chlorine species like $\mathrm{ClO}^{-}\left(\mathrm{E}^{\circ}=\right.$ $0.89 \mathrm{~V}$ vs. NHE) and $\mathrm{Cl}_{2}(1.36 \mathrm{~V} \text { vs. NHE })^{22,40,41}$. As the pKa of $\mathrm{HClO}$ is 7.5, the protonated species predominates when $\mathrm{pH}<7.5$. For this reason, all experiments were performed in acidic medium in order to guarantee that the organic compounds were preferably oxidized by $\mathrm{HClO}$, in order to achieve higher rates of removal and mineralization.

Scialdone $e t a l .{ }^{42}$ emphasize that intermediates of the OER can react with adsorbed chlorine on the electrode, favoring the oxidation of the organic compound (Eqs. 5 and 6).

$\mathrm{MO}_{\mathrm{x}}(\mathrm{OH})+\mathrm{Cl}^{-} \rightarrow \mathrm{MO}_{\mathrm{x}+1}(\mathrm{HClO})+\mathrm{e}^{-}$

Organics $+\mathrm{MO}_{\mathrm{x}+1}(\mathrm{HClO}) \rightarrow$ Intermediates $\rightarrow \mathrm{MO}_{\mathrm{x}}+\mathrm{CO}_{2}+\mathrm{Cl}^{-}+\mathrm{H}_{2} \mathrm{O}+\mathrm{H}_{3} \mathrm{O}^{+}$

Therefore, increasing sodium chloride concentration increases the formation of electrogenerated chlorine species $\left(\mathrm{Cl}_{2} / \mathrm{HClO} / \mathrm{ClO}^{-}\right)$ and the use of high current densities leads to an increase in the amount of these species, allowing alachlor degradation ${ }^{43-45}$. For this reason, the highest removal and mineralization of alachlor was achieved with $0.15 \mathrm{~mol} \mathrm{~L}^{-1} \mathrm{NaCl}$ and current density equal to $50 \mathrm{~mA} \mathrm{~cm}^{-2}$. However, regardless of the tested $\mathrm{NaCl}$ concentrations and current densities, alachlor mineralization was not complete due to the formation of recalcitrant DPs.

\subsubsection{Determination of the energy consumption}

The electric energy consumption may be estimated by the Electric Energy per Order (EEO in $\mathrm{kWh} \mathrm{m}^{-3}$ order $\left.^{-1}\right)$. The EEO is defined as the electric energy in kilowatts per hour $(\mathrm{kWh})$ required to degrade a contaminant $(\mathrm{C})$ by one order of magnitude in $1 \mathrm{~m}^{3}(1,000 \mathrm{~L})$ of water or air, as shown in Eq. $7^{46-49}$, where

$P=$ nominal cell power $/ \mathrm{kW}$,

$t=$ time $/ \mathrm{h}$,

$V=$ volume $/ \mathrm{L}$,

$C_{0}$ and $C_{t}=$ initial and final concentrations of the contaminant, respectively. 
It is important to notice that Eq. 7 is multiplied by 1,000 to convert volume from $\mathrm{L}_{\text {into }} \mathrm{m}^{-3}$ and that it can only be used if the chemical reaction follows a pseudo-first order kinetics, as was the case of alachlor ${ }^{8}$.

$$
E_{E O}\left(k W h m^{-3} \operatorname{order}^{-1}\right)=\frac{P \times t \times 1000}{V \times \log \left(C_{0} / C_{t}\right)}
$$

According to Thiam et al. ${ }^{50}$, the energy consumption can also be expressed per unit of TOC mass, as shown in Eq. 8, where

$E_{\text {cell }}=$ average cell voltage $(\mathrm{V})$,

$I=$ applied current (A),

$t=$ electrolysis time (h),

$V=$ volume $(\mathrm{L})$, and

$\triangle(T O C) \exp$ is the observed TOC decrease $\left(\mathrm{mg} \mathrm{L}^{-1}\right)$.

$$
E C_{T O C}\left(k W h g_{T O C}{ }^{-1}\right)=\frac{E_{c e l l} \times I \times t}{V \times \Delta(T O C)_{\exp }}
$$

Figure 3 shows $E_{E O}$ and $E C_{T O C}$ as a function of the applied current density, calculated for the alachlor degradation experiments. In Fig. 3a, one can notice that, for a fixed current density, as the $\mathrm{NaCl}$ concentration increases, energy consumption decreases. This is because the conductivity of the medium also increases, decreasing cell potential, which leads to lower values of energy consumption, as previously described ${ }^{28,44}$. In addition, for the same concentration of the supporting electrolyte, there is a concomitant increase in energy consumption, due to the cell operational potential increase and the competition between $\mathrm{O}_{2}$ and $\mathrm{Cl}_{2}$ formation at higher potential values $^{44}$. Comparing Fig. $3 \mathrm{a}$ and $3 \mathrm{~b}$, one can observe that the behavior of the energy consumption calculated by Eq. 8 is very similar.

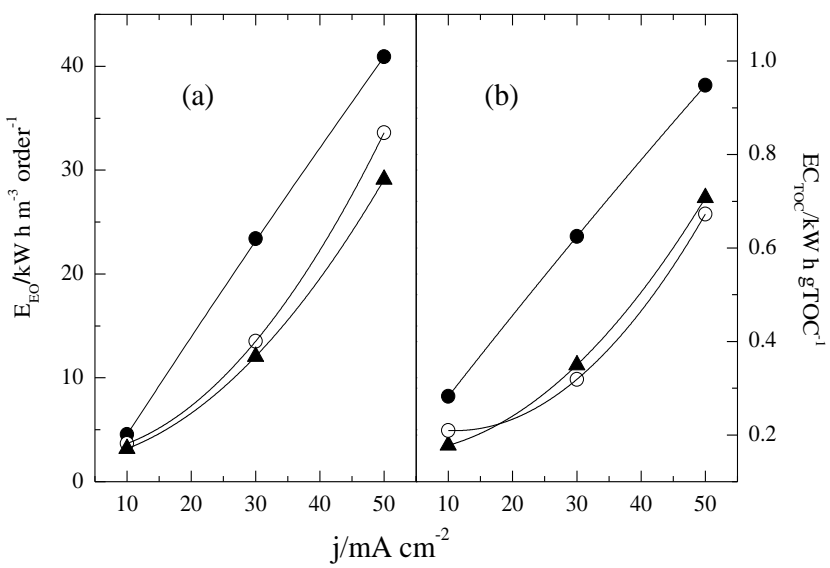

Figure 3. Dependence of energy consumption $\left(\mathrm{kWh} \mathrm{m}^{-3}\right.$ order $^{-1}$ and $\mathrm{kWh}_{\mathrm{TOC}^{-1}}$ ) with applied current density in $\mathrm{NaCl}$ solution: $(\mathbf{O}) 0.05,(\bigcirc) 0.10$ and $(\boldsymbol{\Delta}) 0.15 \mathrm{~mol} \mathrm{~L}^{-1}$. Electrolysis performed using a commercial $\mathrm{Ti} / \mathrm{Ru}_{0.3} \mathrm{Ti}_{0.7} \mathrm{O}_{2}$ DSA anode.

\subsubsection{Electrochemical degradation of atrazine and alachlor-atrazine mixture}

Some of the major companies producing agrochemicals trade alachlor in mixture with atrazine as a way to enhance the action of both herbicides. One of the usual compositions is the ratio of 1:1 (in volume) and, for this reason, the mixture employed in the present work was composed of $0.33 \mathrm{mmol} \mathrm{L}^{-1}$ of each substance.

One can observe that atrazine was removed after $45 \mathrm{~min}$ of electrolysis (Fig. 4), while alachlor took more than 120 min of treatment to reach a similar degradation. 


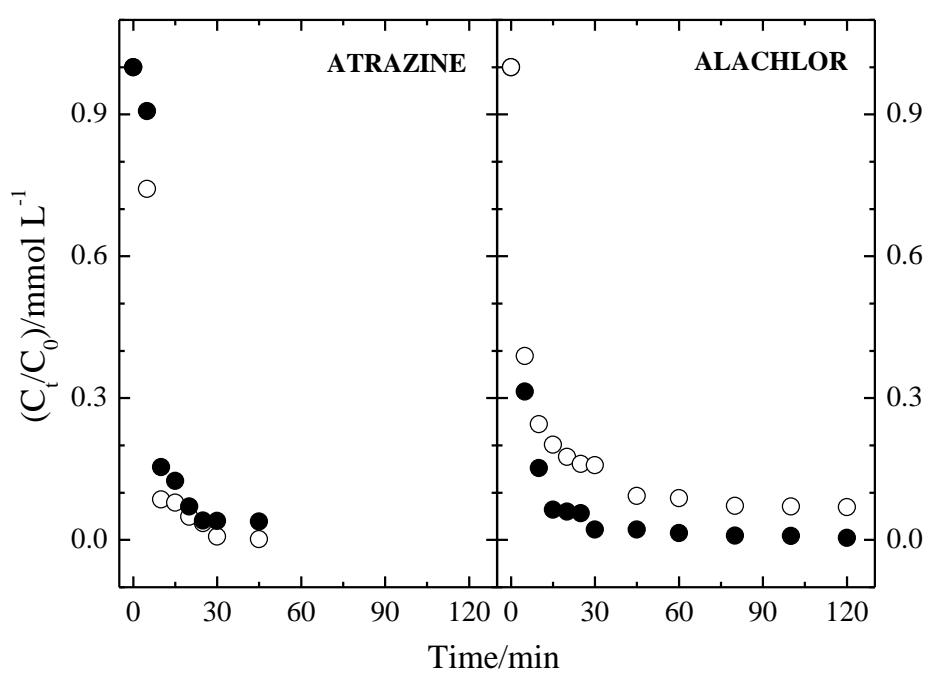

Figure 4. Variation of atrazine and alachlor concentrations with treatment time: $(\bigcirc)$ alone and $(\bigcirc)$ in the mixture.

Energy consumption, TOC, and obtained removals are given in Table 2. One can observe that alachlor alone required more energy to be degraded. In none of the applied conditions the complete mineralization of the compounds was achieved, which can be attributed to the formation of recalcitrant DPs during electrolysis.
Another finding is that, apparently, there is some kind of synergism between alachlor and atrazine. When those two substances were degraded together, alachlor removal and, mainly its mineralization, were increased. Also, energy consumption significantly decreased. The reasons for that behavior are not yet understood. However, that it is a true advantage, as alachlor and atrazine are usually employed together.

Table 2. Results obtained for the removals of alachlor, atrazine and their mixture, mineralization, and energy consumption estimated after electrochemical degradation $\left(120 \mathrm{~min}, 30 \mathrm{~mA} \mathrm{~cm}{ }^{-2}\right.$, and $\left.0.15 \mathrm{~mol} \mathrm{~L}^{-1} \mathrm{NaCl}\right)$.

\begin{tabular}{|c|c|c|c|c|}
\hline Compound & Removal/\% & TOC/\% & $\mathrm{E}_{\mathrm{EO}} / \mathrm{kWh} \mathrm{m}^{-3} \operatorname{order}^{-1}$ & $\mathbf{E C}_{\text {Tос }} / \mathbf{k W h} \mathbf{g}_{\text {тос }}{ }^{-1}$ \\
\hline Alachlor only & 93.1 & 71.0 & 12.1 & 0.35 \\
\hline Atrazine only & 100 & 70.4 & 5.0 & 0.20 \\
\hline $\begin{array}{c}\text { Alachlor-Atrazine } \\
(1: 1)\end{array}$ & $\begin{array}{c}99.6 \\
100\end{array}$ & 82.8 & 7.1 & 0.22 \\
\hline
\end{tabular}

\subsection{Alachlor electrochemical degradation mechanism proposition}

Fig. 5 shows a proposition for the alachlor electrochemical degradation route. The $\mathrm{m} / \mathrm{z}$ ratios here refer to the compounds in their protonated form, $[\mathrm{M}+\mathrm{H}]^{+}$. Initially, the molecular ion that characterizes alachlor was identified with $\mathrm{m} / \mathrm{z}=270$. Partial oxidative cleavage of the bond in the $-\mathrm{OCH}_{3}$ group connected to $\mathrm{N}$, followed by dehalogenation and subsequent hydroxylation leads to the formation of the DP with $\mathrm{m} / \mathrm{z}=222$. This compound also was identified by Pipi et al. ${ }^{8}$ and Wang and Zhang ${ }^{51}$. In addition, this DP was also detected in water samples in Massachusetts ${ }^{3}$.

According to Pipi et al. ${ }^{8}$, the formation of the DP with $\mathrm{m} / \mathrm{z}=284$ is characterized by a purely oxidative mechanism due to hydroxyl radicals. Hydroxyl radicals can also convert lipophilic into 
hydrophilic compounds. That is, from the structural point of view, the DP with $\mathrm{m} / \mathrm{z}=284$ is more soluble in water than its parent compound due to an increased number of polar groups in its structure ${ }^{6}$. The subsequent demethylation followed by the addition of $\mathrm{H}^{+}$leads to the formation of another DP with $\mathrm{m} / \mathrm{z}=270^{8,51}$. DPs with $\mathrm{m} / \mathrm{z}=158,176$, and 224 were also identified in this work. These compounds are quinoline and indoline derivatives, obtained by the complex cleavage of certain bonds followed by cyclization ${ }^{8,52}$.

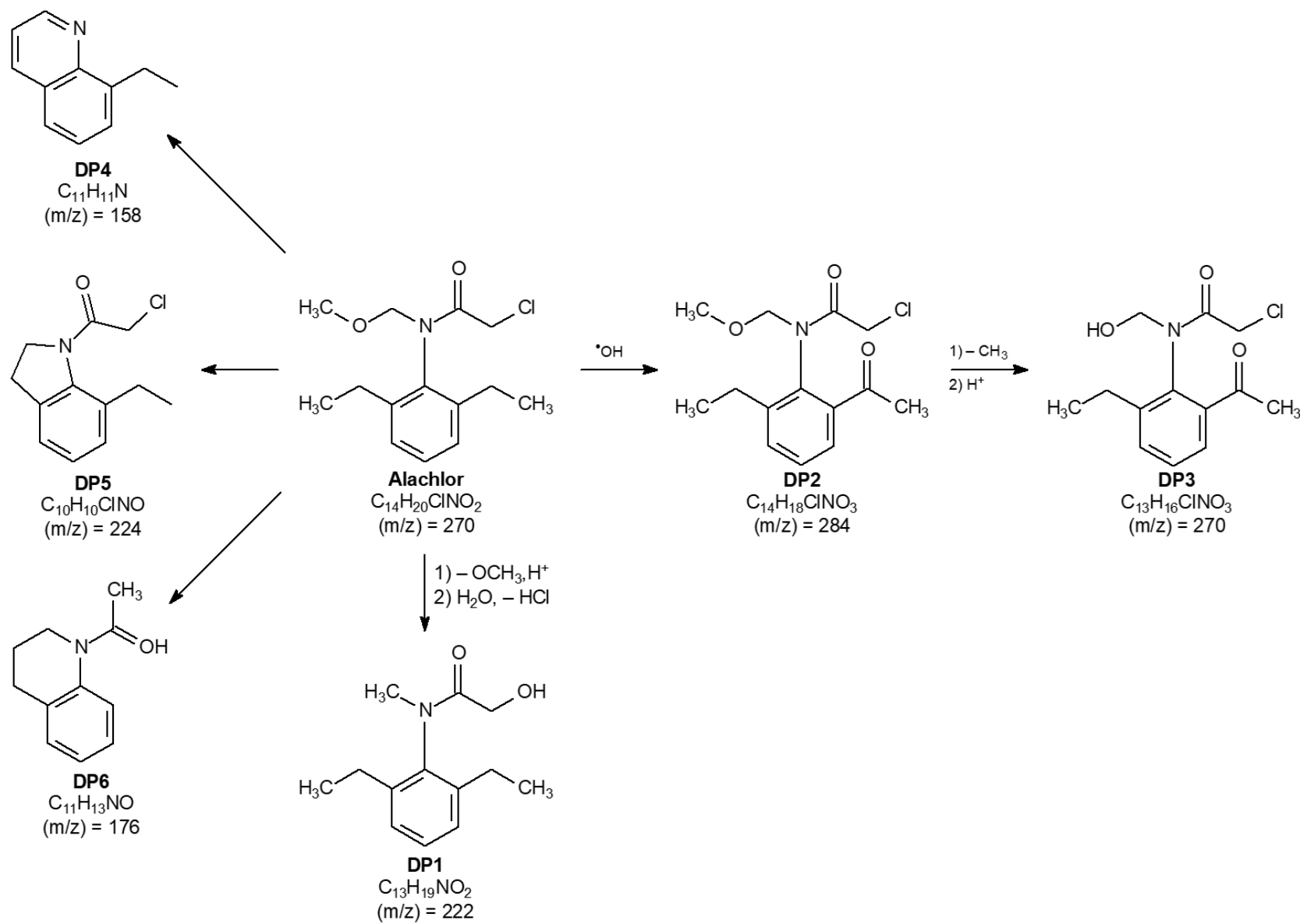

Figure 5. Proposition of the initial mechanism for the electrochemical degradation of alachlor using a commercial $\mathrm{Ti} / \mathrm{Ru}_{0.3} \mathrm{Ti}_{0.7} \mathrm{O}_{2}$ DSA anode in aqueous medium containing $0.15 \mathrm{~mol} \mathrm{~L}^{-1} \mathrm{NaCl}$.

\subsection{Atrazine electrochemical degradation mechanism proposition}

Fig. 6 shows a proposition for the atrazine electrochemical degradation route. The $\mathrm{m} / \mathrm{z}$ ratios of the structures also correspond to the protonated forms, $[\mathrm{M}+\mathrm{H}]^{+}$.

The molecular ion of atrazine has $\mathrm{m} / \mathrm{z}=216$. Dechlorination of atrazine followed by hydroxylation led to the formation of the DP with $\mathrm{m} / \mathrm{z}=198$. This is the main degradation product of atrazine $^{53}$. According to Chen, Yang et $a l^{54}$, the
$\mathrm{C}-\mathrm{Cl}$ bond in atrazine is the lengthiest one, approximately $1.73 \AA$, making it easier to undergo some sort of cleavage. The subsequent deamination with the total loss of the side chain $\left(-\mathrm{NHCH}_{2} \mathrm{CH}_{3}\right)$, followed by hydroxylation forms the DP with $\mathrm{m} / \mathrm{z}=171^{48,54}$.

Two other DPs were identified. The first one, with $\mathrm{m} / \mathrm{z}=218$, was formed by atrazine demethylation followed by hydroxylation. The DP with $\mathrm{m} / \mathrm{z}=232$ was formed due to the abstraction of a hydrogen atom followed by hydroxylation. 
<smiles>CCNc1nc(O)nc(NC(C)C)n1</smiles>

Figure 6. Proposition of the initial mechanism for the electrochemical degradation of atrazine using a commercial $\mathrm{Ti} / \mathrm{Ru}_{0.3} \mathrm{Ti}_{0.7} \mathrm{O}_{2}$ DSA anode in aqueous medium containing $0.15 \mathrm{~mol} \mathrm{~L}^{-1}$ $\mathrm{NaCl}$.

3.5 Lipophilicity and ecotoxicity of alachlor, atrazine, and their degradation products

The distribution coefficients ( $\log \mathrm{D}, \mathrm{pH} 7.4)$ of alachlor, atrazine, and their degradation products (DPs) are presented in Fig. 7.

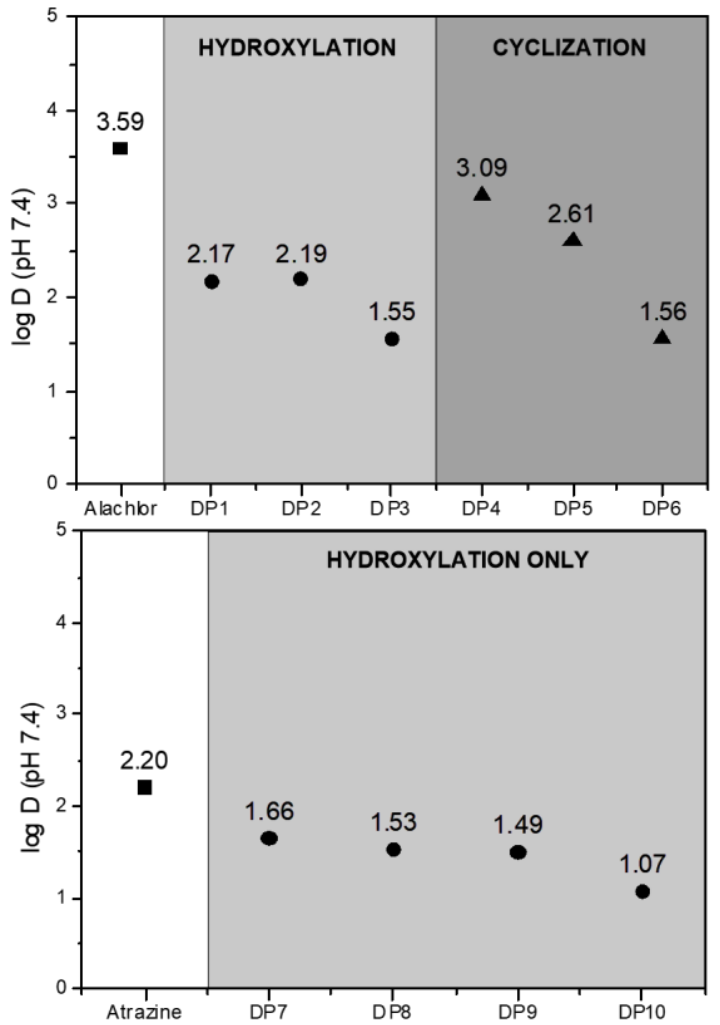

Figure 7. Calculated lipophylicity $(\log \mathrm{D}$ at $\mathrm{pH} 7.4)$ of alachlor, atrazine, and their degradation products.
It is possible to observe that alachlor and its DPs have $\log \mathrm{D}>0$. This is an indication that those compounds preferentially dissolve in non-polar media, representing a risk factor for living beings due to their bioaccumulation potential. The $\log \mathrm{D}$ of all alachlor DPs are smaller than that of alachlor (3.59) due to the insertion of polar groups into their structures during electrolysis, which contribute to the increase in their aqueous solubility, and to smaller carbon chains compared to alachlor.

Among alachlor DPs, those formed by hydroxylation produced, in average, DPs with lower lipophilicity. DP3 is the compound with the lowest calculated lipophilicity ( $\log \mathrm{D} \cong 1.55)$, due to the insertion of a carbonyl in one of the ethyl groups bonded to the aromatic ring and to the replacement of a methoxy group by a hydroxyl one, in one of the carbon chains bonded to the nitrogen atom. Its $\log \mathrm{D}$ is twice as lower as that of alachlor.

In relation to the DPs formed by cyclization, from DP4 (3.09) to DP5 (2.61), log D decreases by one order of magnitude, due to the loss of aromaticity in one of the rings. From DP5 (2.61) to DP6 (1.56), $\log$ D decreases another order of magnitude, due to the loss of the ethyl group bonded to the aromatic ring and dechlorination. DP3 and DP6 have similar lipophilicities.

The lipophilicity of atrazine (2.20) is an order of magnitude lower than that of alachlor (3.59). Atrazine and its DPs have also $\log \mathrm{D}>0$, indicating that their preferably dissolve in non-polar media. The $\log$ D of all atrazine DPs are smaller than that 
of atrazine, in average one order of magnitude lower. The chemical features that make those compounds more water-soluble compared to atrazine are the smaller carbon chains and the increased number of polar groups in their structures.

Figure 8 shows the estimated acute and chronic ecotoxicities for freshwater organisms at three trophic levels (fishes, daphnids and green algae) of alachlor, atrazine and their DPs. It is important to observe that acute toxicity is usually observed within the first $24-48 \mathrm{~h}$ after exposure to the deleterious substance(s), whereas the chronic one is later observed (sometimes weeks or months after the exposure). In this context, the lower the concentration of those compounds that causes harmful effects, the greater their ecotoxicity.

Alachlor acute and chronic estimated ecotoxicities were high for all tested organisms (fishes, daphnids and green algae) (Fig. 8). This

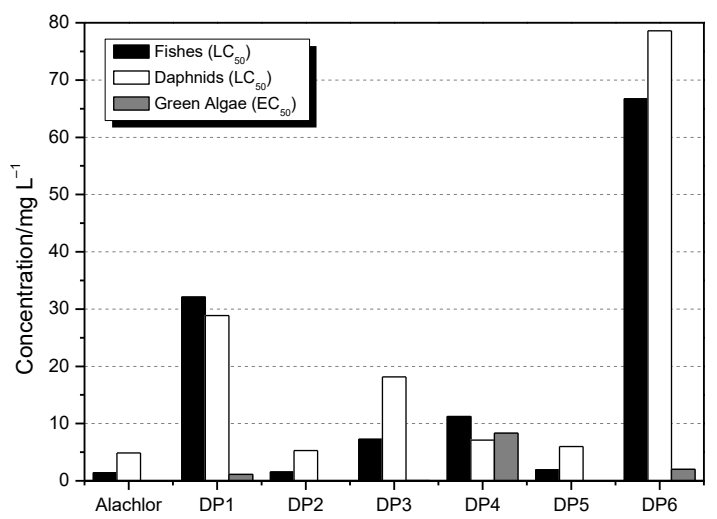

could be attributed to: (i) alachlor is a compound with high $\log$ D value (3.59), which is an indication of its ability to dissolve in fat tissues of animals (fishes and daphnids) and (ii) as alachlor is a herbicide, whose main function is to prevent photosynthesis from happening, it is expected to be quite toxic to green algae. Approximately, the DPs formed from alachlor are equally toxic to fishes and daphnids. That is probably because all degradation products, as well as alachlor, have high lipophilicity.

Among the DPs formed from alachlor, the least toxic is DP6, which is the compound that presented the lowest lipophilicity. Therefore, increased concentrations of those compounds are necessary to harm fishes and daphnids, since they are easier to be eliminated by the organisms. Alachlor is much more toxic than atrazine (16, 4 and 26 times more toxic to fishes, daphnids and green algae, respectively).

(a) Acute ecotoxicity
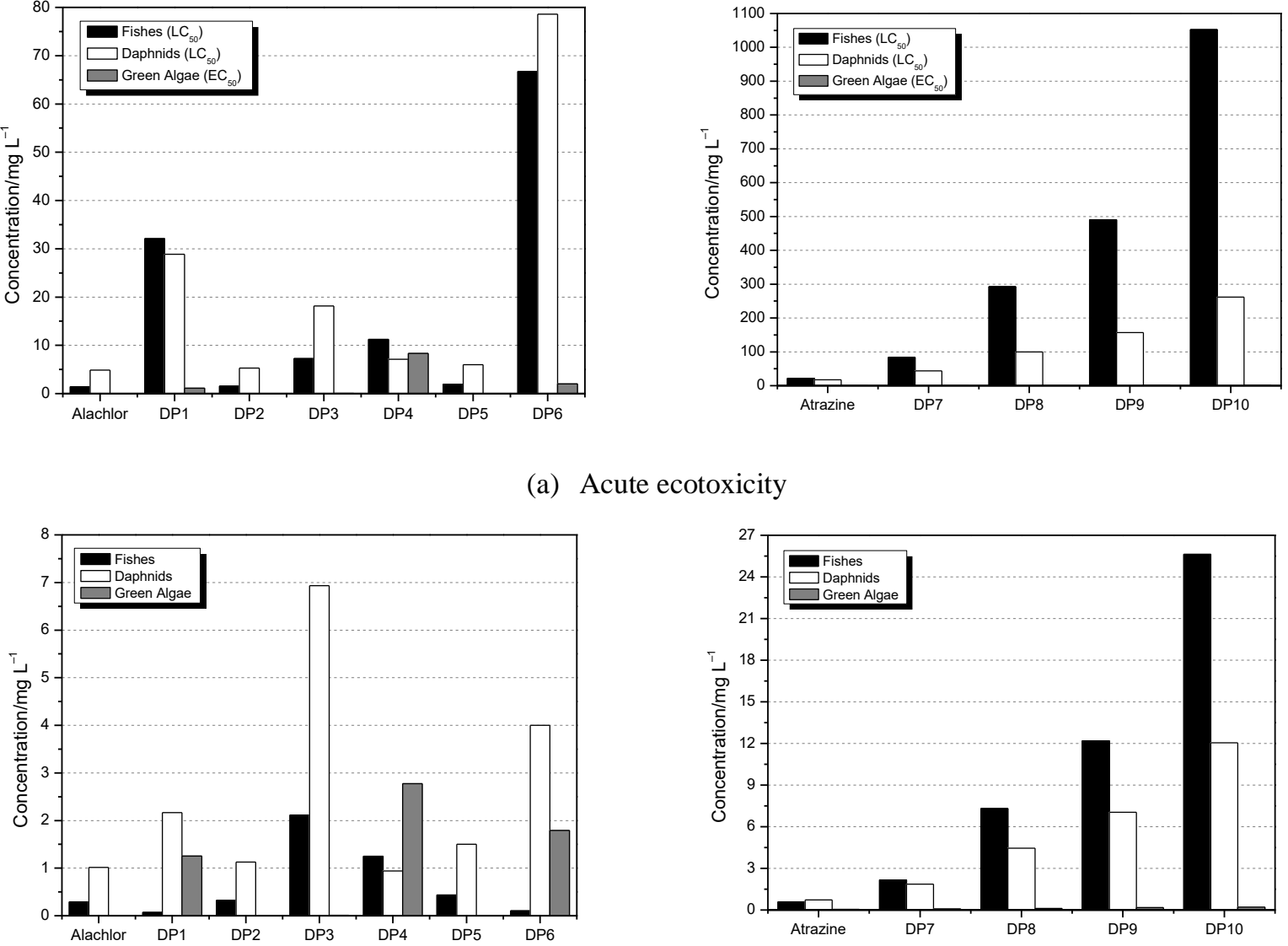

(b) Chronic ecotoxicity

Figure 8. Estimated acute and chronic ecotoxicities of alachlor, atrazine, and their degradation products, using the ECOSAR 1.11 software (USEPA), for three trophic levels: fishes, daphnids and green algae. Chronic ecotoxicities are the geometric mean between the lowest-observed-effect concentration (LOEC) and the no-observed-effect concentration (NOEC). 
Atrazine and its DPs also have high acute ecotoxicities towards green algae due to their herbicidal action, preventing photosynthesis to happen. The atrazine DPs are less toxic to daphnids and fishes compared to atrazine, in the order DP7 $>$ DP8 > DP9 > DP10. This may be ascribed to the partition coefficients of these compounds, which are lower than that of atrazine, making it necessary to increase the DPs concentration to cause fishes and daphnids mortality. In addition, all of atrazine DPs are more toxic to daphnids than to fishes.

Over time, the difference between the ecotoxicities of alachlor and atrazine decreased, so that their chronic ecotoxicities are similar. In addition, it is possible to observe that alachlor (atrazine) concentrations that cause chronic ecotoxicity are on average 10 (40) times lower than those that cause acute ecotoxicity. It is important to emphasize that atrazine and corresponding DPs ecotoxicity profile is quite similar, whether acute or chronic ecotoxicities are considered.

\section{Conclusions}

The DSA in the presence of chloride, led to high removals of alachlor and atrazine due to the formation of active chlorine species with high oxidant power $\left(\mathrm{Cl}_{2} / \mathrm{HOCl} / \mathrm{ClO}^{-}\right)$and the generation of chemically adsorbed hydroxyl radicals on the surface of the electrode. However, in none of the experiments, it was possible to achieve complete mineralization of the organic compounds, due to the formation of recalcitrant DPs (some of which were identified in this work) and to the short electrolysis time (120 min).

The identified DPs of alachlor and atrazine in this work have already been reported in the literature; however, the electrolysis was performed under different conditions. Based on the structures of the DPs identified in this work, it was possible to estimate their acute and chronic ecotoxicities towards three different trophic levels (fishes, daphnids and green algae) and their distribution coefficients $(\log \mathrm{D})$. Those parameters allow one to conclude that all formed DPs have lower pollution potential than their original compounds, although they still pose threats to the environment.

In this context, the present study showed that the electrochemical degradation is effective and can be used for the treatment of residues of pesticides in formulations containing alachlor and atrazine.

\section{References}

[1] Słaba, M., Różalska, S., Bernat, P., Szewczyk, R., Piątek, M. A., Długoński, J., Efficient alachlor degradation by the filamentous fungus Paecilomyces marquandii with simultaneous oxidative stress reduction, Bioresource Technology 197 (Supplement C) (2015) 404-409. https://doi.org/10.1016/j.biortech.2015.08.045.

[2] Pérez, M. H., Vega, L. P., Zúñiga-Benítez, H., Peñuela, G. A., Comparative Degradation of alachlor using photocatalysis and photo-Fenton, Water, Air, \& Soil Pollution $229 \quad$ (11) (2018) 346. https://doi.org/10.1007/s11270-018-3996-6.

[3] Potter, T. L., Carpenter, T. L., Occurrence of alachlor environmental degradation products in groundwater, Environmental Science \& Technology 29 (6) (1995) 1557-1563. https://doi.org/10.1021/es00006a018.

[4] United States Environmental Protection Agency, Registration eligibility decision (RED) alachlor, 1998. https://archive.epa.gov/pesticides/reregistration/web/pd f/0063.pdf.

[5] Chen, C. Z., Yan, C. T., Kumar, P. V., Huang, J. W., Jen, J. F., Determination of alachlor and its metabolite 2,6-diethylaniline in microbial culture medium using online microdialysis enriched-sampling coupled to highperformance liquid chromatography, Journal of Agricultural and Food Chemistry 59 (15) (2011) 80788085. https://doi.org/10.1021/jf201129j.

[6] Kidak, R., Dogan, S., Degradation of trace concentrations of alachlor by medium frequency ultrasound, Chemical Engineering and Processing: Process Intensification 89 (Supplement C) (2015) 19-27. https://doi.org/10.1016/j.cep.2014.12.010.

[7] Mello, R., Santos, L. H. E., Pupo, M. M. S., Eguiluz, K. I. B., Salazar-Banda, G. R., Motheo, A. J., Alachlor removal performance of $\mathrm{Ti} / \mathrm{Ru}_{0.3} \mathrm{Ti}_{0.7} \mathrm{O}_{2}$ anodes prepared from ionic liquid solution, Journal of Solid State Electrochemistry $22 \quad$ (5) (2018) 1571-1580. https://doi.org/10.1007/s10008-017-3700-6.

[8] Pipi, A. R. F., Andrade, A. R., Brillas, E., Sirés, I., Total removal of alachlor from water by electrochemical processes, Separation and Purification Technology 132 (Supplement C) (2014) 674-683. https://doi.org/10.1016/j.seppur.2014.06.022.

[9] Sánchez-Camazano, M., Lorenzo, L. F., SánchezMartín, M. J., Atrazine and alachlor inputs to surface and ground waters in irrigated corn cultivation areas of castilla-leon region, Spain, Environmental Monitoring and Assessment 105 (1) (2005) 11-24. https://doi.org/10.1007/s10661-005-2814-y. 
[10] Spalding, R. F., Exner, M. E., Snow, D. D., Cassada, D. A., Burbach, M. E., Monson, S. J., Herbicides in ground water beneath Nebraska's management systems evaluation area, Journal of Environmental Quality 32 (1) (2003) 92-99. https://doi.org/10.2134/jeq2003.0092.

[11] Guan, S. H., Huang, M. W., Li, X. P., Cai, Q., Determination of atrazine, simazine, alachlor, and metolachlor in surface water using dispersive pipette extraction and gas chromatography-mass spectrometry, Analytical Letters $51 \quad$ (4) (2018) 613-625. https://doi.org/10.1080/00032719.2017.1341904.

[12]Leal, D. P. B., Dick, D. P., Stahl, A. M., Köppchen, S., Burauel, P., Atrazine degradation patterns: the role of straw cover and herbicide application history, Scientia Agricola $76 \quad$ (2019) 63-71. https://doi.org/10.1590/1678-992x-2017-0230.

[13] Aquino, J. M., Miwa, D. W., Rodrigo, M. A., Motheo, A. J., Treatment of actual effluents produced in the manufacturing of atrazine by a photo-electrolytic process, Chemosphere 172 (Supplement C) (2017) 185192.

https://doi.org/10.1016/j.chemosphere.2016.12.154.

[14] Santana, H., Bonancea, C. E., Takashima, K., Photoelectrochemical degradation of atrazina on titanium dioxide: Effect of different experimental parameters, Química Nova 26 (6) (2003) 807-811. https://doi.org/10.1590/s0100-40422003000600005.

[15] United States Environmental Protection Agency, Decision documents for atrazine. 2006. https://swap.stanford.edu/20120106041942/http://www .epa.gov/oppsrrd1/REDs/atrazine_combined_docs.pdf.

[16] Hladik, M. L., Bouwer, E. J., Roberts, A. L., Neutral degradates of chloroacetamide herbicides: Occurrence in drinking water and removal during conventional water treatment, Water Research 42 (20) (2008) 49054914. https://doi.org/10.1016/j.watres.2008.09.008.

[17] Henriet, M. M., Mitchell, R. W., Prill, E. J., Emulsion flowable formulation containing a mixture of alachlor/atrazine as the active agent: Google Patents 1989.

https://patents.google.com/patent/EP0142485B1/en.

[18] Gomes, F. E. R., Souza, N. E., Galinaro, C. A., Arriveti, L. O. R., Assis, J. B., Tremiliosi-Filho, G., Electrochemical degradation of butyl paraben on platinum and glassy carbon electrodes, Journal of Electroanalytical Chemistry 769 (2016) 124-130. https://doi.org/10.1016/j.jelechem.2016.03.016.

[19] Souza, F. L., Aquino, J. M., Miwa, D. W., Rodrigo, M. A., Motheo, A. J., Electrochemical degradation of dimethyl phthalate ester on a DSA ${ }^{\circledR}$ electrode, Journal of the Brazilian Chemical Society 25 (3) (2014) 492501. https://doi.org/10.5935/0103-5053.20140007.

[20] Zheng, D., Xin, Y. J., Ma, D., Wang, X., Wu, J., Gao, M. C., Preparation of graphene/ $/ \mathrm{TiO}_{2}$ nanotube array photoelectrodes and their photocatalytic activity for the degradation of alachlor, Catalysis Science \& Technology $6 \quad$ (6) (2016) 1892-1902. https://doi.org/10.1039/c5cy00887e.

[21] Wardenier, N., Vanraes, P., Nikiforov, A., Van Hulle, S. W. H., Leys, C., Removal of micropollutants from water in a continuous-flow electrical discharge reactor, Journal of Hazardous Materials 362 (2019) 238245. https://doi.org/10.1016/j.jhazmat.2018.08.095.

[22] Fornazari, A. L. T., Malpass, G. R. P., Miwa, D. W., Motheo, A. J., Application of electrochemical degradation of wastewater composed of mixtures of phenol-formaldehyde, Water Air and Soil Pollution 223 (8) (2012) 4895-4904. https://doi.org/10.1007/s11270012-1245-y.

[23] Malpass, G. R. P., Miwa, D. W., Santos, R. L., Vieira, E. M., Motheo, A. J., Unexpected toxicity decrease during photoelectrochemical degradation of atrazine with $\mathrm{NaCl}$, Environmental Chemistry Letters 10 (2) (2012) 177-182. https://doi.org/10.1007/s10311011-0340-4.

[24] Malpass, G. R. P., Salazar-Banda, G. R., Miwa, D. W., Machado, S. A. S., Motheo, A. J., Comparing atrazine and cyanuric acid electro-oxidation on mixed oxide and boron-doped diamond electrodes, Environmental Technology 34 (8) (2013) 1043-1051. https://doi.org/10.1080/09593330.2012.733420.

[25] Rajeshwar, K., Ibanez, J. G., Swain, G. M., Electrochemistry and the environment. Journal of Applied Electrochemistry 24 (11) (1994) 1077-1091. https://doi.org/10.1007/BF00241305.

[26] Pieczyńska, A., Ossowski, T., Bogdanowicz, R., Siedlecka, E., Electrochemical degradation of textile dyes in a flow reactor: effect of operating conditions and dyes chemical structure, International Journal of Environmental Science and Technology 16 (2) (2019) 929-942. https://doi.org/10.1007/s13762-018-1704-0.

[27] Pinto, C. F., Antonelli, R., Araújo, K. S., Fornazari, A. L. T., Fernandes, D. M., Granato, A. C., Azevedo, E. B., Malpass, G. R. P., Experimental-design-guided approach for the removal of atrazine by sonoelectrochemical-UV-chlorine techniques, Environmental Technology 40 (4) (2019) 430-440. https://doi.org/10.1080/09593330.2017.1395480. 
[28] Malpass, G. R. P., Miwa, D. W., Mortari, D. A., Machado, S. A. S., Motheo, A. J., Decolorisation of real textile waste using electrochemical techniques: Effect of the chloride concentration, Water Research 41 (13) (2007)

https://doi.org/10.1016/j.watres.2007.02.054.

2969-2977.

[29] Parra, K. N., Gul, S., Aquino, J. M., Miwa, D. W., Motheo, A. J., Electrochemical degradation of tetracycline in artificial urine medium, Journal of Solid State Electrochemistry 20 (4) (2016) 1001-1009. https://doi.org/10.1007/s10008-015-2833-8.

[30] Hussain, S., Gul, S., Steter, J. R., Miwa, D. W., Motheo, A. J., Route of electrochemical oxidation of the antibiotic sulfamethoxazole on a mixed oxide anode, Environmental Science and Pollution Research 22 (19) (2015) 15004-15015. https://doi.org/10.1007/s11356015-4699-9.

[31] Malpass, G. R. P., Miwa, D. W., Gomes, L., Azevedo, E. B., Vilela, W. F. D., Fukunaga, M. T., Guimaraes, J. R., Bertazzoli, R., Machado, S. A. S., Motheo, A. J., Photo-assisted electrochemical degradation of the commercial herbicide atrazine, Water Science and Technology 62 (12) (2010) 2729-2736. https://doi.org/10.2166/wst.2010.207.

[32] Malpass, G. R. P., Miwa, D. W., Machado, S. A. S., Motheo, A. J., $\mathrm{SnO}_{2}$-based materials for pesticide degradation, Journal of Hazardous Materials 180 (1-3) (2010) $145-151$. https://doi.org/10.1016/j.jhazmat.2010.04.006.

[33] Montes, I. J. S., Silva, B. F., Aquino, J. M., On the performance of a hybrid process to mineralize the herbicide tebuthiuron using a DSA ${ }^{\circledR}$ anode and UVC light: A mechanistic study, Applied Catalysis B$\begin{array}{llll}\text { Environmental } \quad 200 \quad \text { (2017) } & 237-245 .\end{array}$ https://doi.org/10.1016/j.apcatb.2016.07.003.

[34] Santos, T. E. S., Silva, R. S., Meneses, C. T., Martinez-Huitle, C. A., Eguiluz, K. I. B., Salazar-Banda, G. R., Unexpected enhancement of electrocatalytic nature of $\mathrm{Ti} /\left(\mathrm{RuO}_{2}\right)(\mathrm{x})-\left(\mathrm{Sb}_{2} \mathrm{O}_{5}\right)(\mathrm{y})$ anodes prepared by the ionic liquid-thermal decomposition method, Industrial \& Engineering Chemistry Research 55 (11) (2016) 3182-3187. https://doi.org/10.1021/acs.iecr.5b04690.

[35] Bharate, S. S., Kumar, V., Vishwakarma, R. A., Determining partition coefficient (Log P), distribution coefficient (Log D) and ionization constant (pKa) in early drug discovery, Combinatorial Chemistry \& High Throughput Screening 19 (6) (2016) 461-469. https://doi.org/10.2174/1386207319666160502123917.

[36] Csizmadia, F., Tsantili-Kakoulidou, A., Panderi, I., Darvas, F., Prediction of distribution coefficient from structure .1. Estimation method, Journal of Pharmaceutical Sciences 86 (7) (1997) 865-871. https://doi.org/10.1021/js960177k.

[37]Zhang, H., Liu, F., Wu, X. G., Zhang, J. H., Zhang, D. B., Degradation of tetracycline in aqueous medium by electrochemical method, Asia-Pacific Journal of Chemical Engineering 4 (5) (2009) 568-573. https://doi.org/10.1002/apj.286.

[38] Rajkumar, D., Kim, J. G., Oxidation of various reactive dyes with in situ electro-generated active chlorine for textile dyeing industry wastewater treatment, Journal of Hazardous Materials 136 (2) (2006) 203-212. https://doi.org/10.1016/j.hazement.2005.11.096.

[39] Trasatti, S., Electrocatalysis: understanding the success of $\mathrm{DSA}^{\circledR}$, Electrochimica Acta 45 (15-16) (2000) 2377-2385. https://doi.org/10.1016/s00134686(00)00338-8.

[40] Cheng, C. Y., Kelsall, G. H., Models of hypochlorite production in electrochemical reactors with plate and porous anodes, Journal of Applied Electrochemistry $37 \quad$ (11) (2007) 1203-1217. https://doi.org/10.1007/s10800-007-9364-7.

[41] Pipi, A. R. F., Aquino Neto, S., Andrade, A. R., Electrochemical degradation of diuron in chloride medium using $\mathrm{DSA}^{\circledR}$ based anodes, Journal of the Brazilian Chemical Society 24 (8) (2013) 1259-1266. https://doi.org/10.5935/0103-5053.20130159.

[42] Scialdone, O., Randazzo, S., Galia, A.,Silvestri, G., Electrochemical oxidation of organics in water: Role of operative parameters in the absence and in the presence of NaCl, Water Research 43 (8) (2009) 2260-2272. https://doi.org/10.1016/j.watres.2009.02.014.

[43] Chauhan, R., Srivastava, V. C., Hiwarkar, A. D., Electrochemical mineralization of chlorophenol by ruthenium oxide coated titanium electrode, Journal of the Taiwan Institute of Chemical Engineers 69 (2016) 106-117. https://doi.org/10.1016/j.jtice.2016.10.016.

[44] Gomes, L., Miwa, D. W., Malpass, G. R. P., Motheo, A. J., Electrochemical degradation of the dye reactive orange 16 using electrochemical flow-cell, Journal of the Brazilian Chemical Society 22 (7) (2011) 1299-1306. https://doi.org/10.1590/s010350532011000700015 .

[45] Hussain, S., Steter, J. R., Gul, S.,Motheo, A. J., Photo-assisted electrochemical degradation of sulfamethoxazole using a $\mathrm{Ti} / \mathrm{Ru}_{0.3} \mathrm{Ti}_{0.7} \mathrm{O}_{2}$ anode: Mechanistic and kinetic features of the process, Journal of Environmental Management 201 (2017) 153-162. https://doi.org/10.1016/j.jenvman.2017.06.043. 
[46] Bessegato, G. G., Cardoso, J. C., Silva, B. F., Zanoni, M. V. B., Combination of photoelectrocatalysis and ozonation: A novel and powerful approach applied in acid yellow 1 mineralization, Applied Catalysis B$\begin{array}{llll}\text { Environmental } & 180 & \text { (2016) }\end{array}$ https://doi.org/10.1016/j.apcatb.2015.06.013.

[47] Bolton, J. R., Bircher, K. G., Tumas, W., Tolman, C. A., Figures-of-merit for the technical development and application of advanced oxidation technologies for both electric- and solar-driven systems (IUPAC Technical Report), Pure and Applied Chemistry 73 (4) (2001) 627-637. https://doi.org/10.1351/pac200173040627.

[48] Khan, J. A., He, X., Shah, N. S., Khan, H. M., Hapeshi, E., Fatta-Kassinos, D., Dionysiou, D. D., Kinetic and mechanism investigation on the photochemical degradation of atrazine with activated $\mathrm{H}_{2} \mathrm{O}_{2}, \mathrm{~S}_{2} \mathrm{O}_{8}{ }^{2-}$ and $\mathrm{HSO}_{5}$, Chemical Engineering Journal 252 (2014) 393-403. https://doi.org/10.1016/j.cej.2014.04.104.

[49] Malpass, G. R. P., Miwa, D. W., Machado, S. A. S., Motheo, A. J., Decolourisation of real textile waste using electrochemical techniques: Effect of electrode composition, Journal of Hazardous Materials 156 (1-3) (2008) $170-177$. https://doi.org/10.1016/j.jhazmat.2007.12.017.

[50] Thiam, A., Salazar, R., Brillas, E., Sirés, I., Electrochemical advanced oxidation of carbofuran in aqueous sulfate and/or chloride media using a flow cell with a $\mathrm{RuO}_{2}$-based anode and an air-diffusion cathode at pre-pilot scale, Chemical Engineering Journal 335 (2018) 133-144. https://doi.org/10.1016/j.cej.2017.10.137.

[51] Wang, X. K., Zhang, Y., Degradation of alachlor in aqueous solution by using hydrodynamic cavitation, Journal of Hazardous Materials 161 (1) (2009) 202-207. https://doi.org/10.1016/j.jhazmat.2008.03.073.

[52] Qiang, Z. M., Liu, C., Dong, B. Z., Zhang, Y. L., Degradation mechanism of alachlor during direct ozonation and $\mathrm{O}_{3} / \mathrm{H}_{2} \mathrm{O}_{2}$ advanced oxidation process, Chemosphere $78 \quad$ (5) (2010) 517-526. https://doi.org/10.1016/j.chemosphere.2009.11.037.

[53] Javaroni, R. D. A., Landgraf, M. D., Rezende, M. O. O., Behavior of the herbicides atrazine and alachlor after application on soils prepared to sugar cane plantation, Química Nova 22 (1) (1999) 58-64. http://doi.org/10.1590/S0100-40421999000100012.

[54] Chen, C., Yang, S. G., Guo, Y. P., Sun, C., Gu, C. G., Xu, B., Photolytic destruction of endocrine disruptor atrazine in aqueous solution under UV irradiation: Products and pathways, Journal of Hazardous Materials
$172 \quad(2-3) \quad$ 675-684.

https://doi.org/10.1016/j.jhazmat.2009.07.050. 